\title{
Interventions to improve exercise behaviour in sedentary people living with and beyond cancer: a systematic review
}

\author{
L Bourke $^{*}$, , K E Homer ${ }^{1}$, M A Thaha ${ }^{2}$, L Steed ${ }^{1}$, D J Rosario ${ }^{3}$, K A Robb ${ }^{4}$, J M Saxton ${ }^{5}$ and S J C Taylor ${ }^{1}$ \\ ${ }^{1}$ Department of Primary Care and Public Health, Barts and The London School of Medicine and Dentistry, Blizard Institute, Queen \\ Mary University of London, London, UK; ${ }^{2}$ Academic Surgical Unit, Centre for Digestive Diseases, Barts and The London School of \\ Medicine and Dentistry, Blizard Institute, Queen Mary University London, London, UK; ${ }^{3}$ Academic Urology Unit, Department \\ of Oncology, E Floor, Royal Hallamshire Hospital, University of Sheffield, Glossop Road, Sheffield, UK; ${ }^{4}$ Department of \\ Physiotherapy, Bart's Hospital, London, UK and ${ }^{5}$ School of Allied Health Professions, University of East Anglia, Norwich, UK
}

Background: To systematically review the effects of interventions to improve exercise behaviour in sedentary people living with and beyond cancer.

Methods: Only randomised controlled trials (RCTs) that compared an exercise intervention to a usual care comparison in sedentary people with a homogeneous primary cancer diagnosis, over the age of 18 years were eligible. The following electronic databases were searched: Cochrane Central Register of Controlled Trials MEDLINE; EMBASE; AMED; CINAHL; PsycINFO; SportDiscus; PEDro from inception to August 2012.

Results: Fourteen trials were included in this review, involving a total of 648 participants. Just six trials incorporated prescriptions that would meet current recommendations for aerobic exercise. However, none of the trials included in this review reported intervention adherence of $75 \%$ or more for a set prescription that would meet current aerobic exercise guidelines. Despite uncertainty around adherence in many of the included trials, the interventions caused improvements in aerobic exercise tolerance at 8-12 weeks $(\mathrm{SMD}=0.73,95 \% \mathrm{Cl}=0.51-0.95)$ in intervention participants compared with controls. At 6 months, aerobic exercise tolerance is also improved $(S M D=0.70,95 \% \mathrm{Cl}=0.45-0.94)$, although four of the five trials had a high risk of bias; hence, caution is warranted in its interpretation.

Conclusion: Expecting the majority of sedentary survivors to achieve the current exercise guidelines is likely to be unrealistic. As with all well-designed exercise programmes, prescriptions should be designed around individual capabilities and frequency, duration and intensity or sets, repetitions, intensity of resistance training should be generated on this basis.

It is estimated that there are now around 29 million people living with or beyond cancer globally (excl. non-melanoma skin cancer) (GLOBOCAN, 2008), and this number will continue to rise as a result of an ageing population, increased detection and improving survival (Maddams et al, 2009). For many cancer survivors, iatrogenic harm caused by primary treatment, and the transition from end of treatment to living beyond cancer, can have an impact on all aspects of life for the individuals and their families (Ferrell et al, 1998).
Europe's largest survey assessing patient-reported outcomes in people living with and beyond cancer reported that $<25 \%$ meet the current physical activity guidelines, $43 \%$ have trouble with fatigue and $45 \%$ experience fear of disease recurrence (Department of Health-Quality Health, 2012). Furthermore, around 50\% of people with cancer have an existing chronic condition (Elliott et al, 2011) and are at an increased risk of developing new comorbidities such as heart failure, coronary heart disease, osteoporosis and diabetes

*Correspondence: Dr L Bourke; E-mail: I.bourke@qmul.ac.uk

Received 17 October 2013; accepted 1 November 2013; published online 12 December 2013

(c) 2014 Cancer Research UK. All rights reserved 0007-0920/14 
during the survivorship period (Khan et al, 2011). For these individuals, the proportion suffering on-going poor health, quality of life and disability may be as high as $25-30 \%$ (Elliott et al, 2011).

Exercise interventions for cancer survivors have received increasing attention over the last decade as an effective way to improve health-related quality of life, physical function and reduce fatigue (Fong et al, 2012; Mishra et al, 2012a, b). Associations with the reduced risk of disease recurrence have also come to prominence (Holmes et al, 2005; Meyerhardt et al, 2006, 2009; Kenfield et al, 2011; Richman et al, 2011). The current exercise guidelines indicate that cancer survivors should achieve $150 \mathrm{~min}$ per week of aerobic exercise and twice weekly resistance (strength) training (Rock et al, 2012). However, as few individuals achieve such physical activity levels, a comprehensive review of behaviourchange effectiveness including which interventions meet the current guidelines is crucial. The aim of this study was to systematically review the effects of exercise interventions on exercise behaviour in sedentary people living with and beyond cancer.

\section{MATERIALS AND METHODS}

Search strategy. Full details of the MEDLINE search (which was adapted accordingly for separate databases) can be seen in the parallel publication of Bourke et al (2013). Briefly, the following electronic databases were searched: Cochrane Central Register of Controlled Trials MEDLINE; EMBASE; AMED; CINAHL; PsycINFO; SportDiscus; PEDro from inception to August 2012. To supplement this evidence, grey literature was evaluated, leading experts in the field and charities were written to and reference lists of other recent systematic reviews were screened for potential trials.

Eligible studies. Only randomised controlled trials (RCTs) involving adults (18 years or over) that aimed to improve exercise behaviour compared with a usual care comparison group with a sedentary lifestyle (i.e., not undertaking $30 \mathrm{~min}$ or more of the structured exercise of at least a moderate intensity, 3 days per week) were included. Participants were required to have been histologically or clinically diagnosed with cancer regardless of sex, tumour site, tumour type, tumour stage and type of anticancer treatment received. Only interventions that detailed the frequency, duration and intensity of aerobic exercise behaviour, or the frequency, intensity, type, sets, repetitions of resistance exercise behaviour were included. The exercise programmes could be individual or group, professionally led or not, and home, community, primary care or exercise facility based. Eligible RCTs must have included at least 6 weeks of follow-up.

In an effort to attempt to understand how different interventions might be relevant to each type of cancer and its specific treatment methods, we did not include studies of heterogeneous cancer cohorts (i.e., patients with different primary cancer sites). Studies in 'at risk' populations that are addressing primary prevention research questions were not included. Trials directed specifically at end-of-life-care pathways or hospital in-patients were also excluded.

Study quality. Risk of bias and methodological quality were assessed in accordance with the Cochrane Collaboration's tool for assessing risk of bias (Higgins and Green, 2011). Two review authors (LB and $\mathrm{KH}$ ) applied the risk of bias tool independently, and any differences were resolved by discussion with a third review author (ST or DR).

Outcomes. Primary outcomes were aerobic exercise behaviour (frequency, duration and intensity) and resistance exercise behaviour (sets, repetitions and intensity). Interventions were judged as successful in achieving their exercise goals as identified in the study methods if they reported at least $75 \%$ adherence over the given follow-up period (Martin and Sinden, 2001). We also assessed which interventions were designed to achieve the American Cancer Society's guidelines for exercise in people living with and beyond cancer - that is aerobic exercise of at least 150 min per week - with at least 2 days per week of strength training (Rock et al, 2012). Secondary outcomes were change in aerobic fitness or exercise tolerance, change in skeletal muscle strength and endurance, adverse events and intervention attrition rate.

Screening and data extraction. All titles and abstracts were screened to identify studies that might meet the inclusion criteria or that could not safely be excluded without full-text assessment (e.g., where there is no abstract available) by two of the authors working independently (LB and $\mathrm{KH}$ ). Full texts were retrieved for these articles. All eligible papers were formally abstracted by at least two members of the group working independently (LB and $\mathrm{KH}$ ) using the data collection form and the risk of bias tool (Higgins and Green, 2011). Any disagreements were resolved by discussion with one more review author (ST or DJR).

Data synthesis. Data on adherence were quantified in terms of number of prescribed exercise sessions attended as a proportion of those prescribed. Interventions were categorised in terms of the behaviour-change techniques (BCTs) used according to the 'Coventry, Aberdeen \& London-Refined' (CALO-RE) taxonomy by a health psychologist trained in using this taxonomy (LS) and checked by LB (Michie et al, 2011). Where possible, and if appropriate, meta-analyses of review outcomes were performed. A fixed-effect model was used if there was no significant statistical heterogeneity $\left(I^{2} \geqslant 50 \%\right)$. For continuous outcomes (e.g., fitness or exercise tolerance), the standardised mean difference between treatment arms was estimated by extracting the final value and standard deviation of the outcome of interest with the number of participants assessed at follow-up. The Cochrane group RevMan version 5.2 statistical analysis software was used to carry out metaanalyses (Cochrane IMS, 2013).

\section{RESULTS}

We identified 5559 unique records from research database records from grey literature and 'snowballing' techniques, which included reference checking from recent large systematic reviews (see Figure 1, PRISMA flow chart). Given that the detail of prescribed exercise is rarely reported in manuscript abstracts (e.g., frequency, intensity and duration of exercise prescription), this led to a large number of manuscripts being evaluated at the full-text stage $(n=402)$. After consensus agreement between study authors, 14 RCTs were included in this review (McKenzie and Kalda, 2003; Pinto et al, 2003, 2005, 2013; Drouin et al, 2005; Kim et al, 2006; Daley et al, 2007; Cadmus et al, 2009; Hayes et al, 2009; Perna et al, 2010; Kaltsatou et al, 2011; Bourke et al, 2011a, b; Musanti, 2012). A total of 648 participants were randomised in these trials. A total of 377 reports were excluded; reasons for exclusion were: non RCTs - for example, reviews or comment/editorial articles; mixed cancer cohorts or cohorts that included non-cancer populations; trials that failed to describe essential metrics of exercise prescription used in the intervention; trials involving active participants at baseline; trials involving hospital in-patients; interventions that were $<6$ weeks in follow-up; trials involving participants $<18$ years of age; not able to translate into English.

The majority of trials were conducted in breast cancer survivors with only two trials in colorectal (Bourke et al, 2011b; Pinto et al, 2013) and one trial in prostate cancer (Bourke et al, 2011a). A summary of study characteristics can be seen in Table 1 . We only found one study that reported data from patients with metastatic disease (Bourke et al, 2011a) and two studies that were conducted 


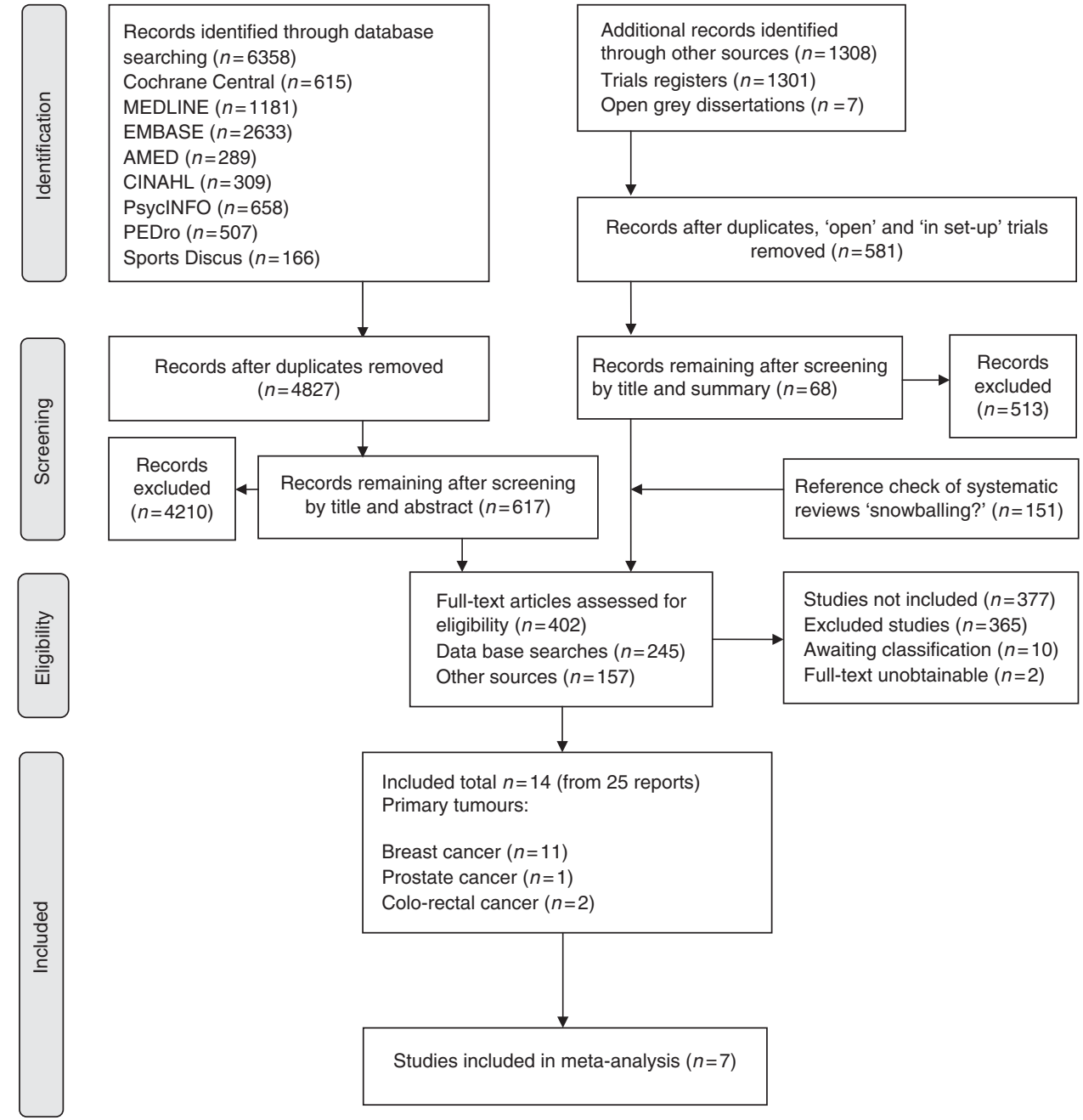

Figure 1. PRISMA flow diagram of included and excluded studies.

in obese cohorts (Drouin et al, 2005; Cadmus et al, 2009). The overwhelming proportions of participants were White, with only one study reporting data from an ethnically diverse sample (Perna et al, 2010). Comorbidities at baseline were largely unclear or unreported, with only two studies (Daley et al, 2007; Hayes et al, 2009) reporting on proportion with lymphedema, and one trial reporting on proportion with clinically relevant depression scores (Perna et al, 2010).

Seven trials used a combination of supervised and nonsupervised exercises (Pinto et al, 2003; Kim et al, 2006; Cadmus et al, 2009; Hayes et al, 2009; Perna et al, 2010; Bourke et al, 2011a, b); four trials were exclusively home-based (Drouin et al, 2005; Pinto et al, 2005, 2013; Musanti, 2012); and just three were exclusively supervised trials (McKenzie and Kalda, 2003; Daley et al, 2007; Kaltsatou et al, 2011). Contact with exercise professionals or study researchers ranged from 20 times over 12 weeks (Hayes et al, 2009) to weekly phone calls after an initial oneto-one exercise consultation (Pinto et al, 2005, 2013). Just six trials incorporated prescriptions that would meet the Rock et al (2012) recommendations for aerobic exercise, that is, $150 \mathrm{~min}$ per week (Cadmus et al, 2009; Pinto et al, 2013) or resistance exercise, that is, strength training exercises at least 2 days per week (Perna et al, 2010; Bourke et al, 2011a, b; Musanti, 2012). Only three trials were identified that attempted to objectively validate independent exercise behaviour with accelerometers or heart rate monitoring (Pinto et al, 2005, 2013; Cadmus et al, 2009). A summary of included studies can be seen in Table 2 .
Quality of studies. Three trials were judged not to include a high risk of bias (Drouin et al, 2005; Cadmus et al, 2009; Bourke et al, $2011 \mathrm{~b}$ ). The majority of uncertainty in judging trial bias came from a lack of clarity around randomisation procedures and blinding of study outcome assessors (McKenzie and Kalda, 2003; Pinto et al, 2003, 2005, 2013; Kaltsatou et al, 2011). The majority of trials in the review were judged to include at least one element indicating a high risk of non-standard bias. These included adherence data missing or not clear (McKenzie and Kalda, 2003; Hayes et al, 2009; Kaltsatou et al, 2011; Musanti, 2012); high attrition at follow-up (Pinto et al, 2003; Bourke et al, 2011a); significant differences in those participants excluded from trial analysis/dropouts (Pinto et al, 2003; Kim et al, 2006; Musanti, 2012); numbers randomised to trial arms and trial completion rate are unclear (Perna et al, 2010); significant differences in cohorts at baseline (Pinto et al, 2003, 2005; Musanti, 2012); inconsistencies between objective and subjective measures of exercise behaviour (Pinto et al, 2005, 2013).

Effects of the interventions. None of the trials included in this review reported an adherence of $75 \%$ or more, to a prescription that would meet the Rock et al (2012) aerobic exercise guidelines. Only three trials reported an adherence of $75 \%$ or more to a lower aerobic exercise goal (Cadmus et al, 2009; Bourke et al, 2011a, b). Notably, all three incorporated both a supervised and independent exercise component as part of their intervention and none placed restrictions on the control group in terms of their exercise behaviour. Cadmus et al (2009) appeared to be the most successful 
Table 1. Characteristics of included studies

\begin{tabular}{|c|c|c|c|c|c|}
\hline Study & $\begin{array}{l}\mathrm{N} \text { and primary } \\
\text { cancer }\end{array}$ & Current treatment & $\begin{array}{l}\text { Exercise prescription } \\
\text { components }\end{array}$ & $\begin{array}{l}\text { Method of measuring } \\
\text { exercise behaviour }\end{array}$ & Instructions to controls \\
\hline Cadmus et al, 2009 & $\begin{array}{l}\text { 37, } 38 \text { (Intervention } \\
\text { vs control): } \mathrm{BCa}\end{array}$ & $\begin{array}{l}\text { Completed adjuvant } \\
\text { treatment (with the exception } \\
\text { of hormonal therapy) at least } \\
6 \text { months before enrolment. } \\
57 \% \text { vs } 70 \% \text { on hormone } \\
\text { therapy in the intervention } \\
\text { group vs controls; } 30 \% \text { on } \\
\text { tamoxifen in both arms; } 27 \text { vs } \\
40 \% \text { vs control on aromatase } \\
\text { inhibitors }\end{array}$ & $\begin{array}{l}\text { Aerobic exercise. } \\
\text { Frequency: three sessions per } \\
\text { week supervised, two } \\
\text { sessions per week at home or } \\
\text { at a health club: total } 5 \text { days a } \\
\text { week. Duration: participants } \\
\text { were asked to perform three } \\
15 \text { min sessions during week } 1 \text {, } \\
\text { building to five } 30 \text { min } \\
\text { moderate-intensity sessions } \\
\text { by week } 5 \text {. Intensity: } 60-80 \% \\
\text { of maximal heart rate reserve }\end{array}$ & $\begin{array}{l}\text { Heart rate monitors, physical } \\
\text { activity questionnaire, a } \\
7 \text { day physical activity log, } \\
\text { and a } 7 \text { day pedometer log. } \\
\text { Adherence to the } \\
\text { intervention among exercise } \\
\text { group participants was } \\
\text { assessed with } 7 \text { day physical } \\
\text { activity logs weekly }\end{array}$ & $\begin{array}{l}\text { Can exercise on their own if } \\
\text { they chose }\end{array}$ \\
\hline Daley et al, 2007 & $\begin{array}{l}34 ; 36 ; 38 \\
\text { (Intervention; } \\
\text { sham; control, } \\
\text { respectively): BCa }\end{array}$ & $\begin{array}{l}73.5 \%, 69.4 \%, 76.3 \% \text { On } \\
\text { hormone therapy in the } \\
\text { intervention, sham, and usual } \\
\text { care groups, respectively }\end{array}$ & $\begin{array}{l}\text { Aerobic exercise. } \\
\text { Frequency: three sessions per } \\
\text { week. Duration: } 27 \text { min of } \\
\text { exercise on average } \\
\text { per session. Intensity: } 65 \% \text { to } \\
85 \% \text { of age-adjusted heart } \\
\text { rate maximum and RPE of } \\
12-13\end{array}$ & $\begin{array}{l}\text { Adherence was calculated } \\
\text { from session attendance and } \\
\text { the amount (duration, RPE, } \\
\text { heart rate) of exercise } \\
\text { achieved by participants } \\
\text { during sessions was } \\
\text { calculated by extraction from } \\
\text { physical activity logs }\end{array}$ & Continue with lives as usual \\
\hline Drouin et al, 2005 & $\begin{array}{l}13 \text { Intervention, } 8 \\
\text { placebo stretching } \\
\text { controls: } \mathrm{BCa}\end{array}$ & $\begin{array}{l}\text { External beam radiation on } \\
5 \text { days per week for } 7 \text { weeks. } \\
\text { The affected breast and } \\
\text { regional lymph nodes } \\
\text { received a } 4500 \text { to } 5000 \text { cGy } \\
\text { dose in } 200 \text { cGy fractions with } \\
\text { a boost of } 1000-1600 \text { cGy } \\
\text { delivered to the primary } \\
\text { tumour bed }\end{array}$ & $\begin{array}{l}\text { Aerobic exercise. } \\
\text { Frequency: three to five } \\
\text { times per week. Duration: } \\
20-45 \text { min. Intensity: } 50-70 \% \\
\text { of the maximal heart rate } \\
\text { achieved by the participant } \\
\text { during a symptom-limited } \\
\text { graded exercise test }\end{array}$ & $\begin{array}{l}\text { Participants were provided } \\
\text { with a training diary to } \\
\text { record. Participants in the } \\
\text { intervention group wore } \\
\text { heart rate monitors to record } \\
\text { training time and time spent } \\
\text { in the training heart rate } \\
\text { range to improve reporting of } \\
\text { data on exercise compliance, } \\
\text { training intensity and training } \\
\text { duration }\end{array}$ & $\begin{array}{l}\text { Not to begin any new } \\
\text { exercise activity other than a } \\
\text { general flexibility } \\
\text { programme they were given }\end{array}$ \\
\hline $\begin{array}{l}\text { Kaltsatou et al, } \\
2011\end{array}$ & $\begin{array}{l}\text { 14,13 (Intervention } \\
\text { vs control): } \mathrm{BCa}\end{array}$ & Treatment completed & $\begin{array}{l}\text { Aerobic exercise. } \\
\text { Frequency: three times per } \\
\text { week. Duration: the aerobic } \\
\text { training phase lasted } 25 \text { min } \\
\text { and included learning and } \\
\text { practising Greek traditional } \\
\text { dances. Intensity: between } \\
65 \text { and } 80 \% \text { of maximum } \\
\text { heart rate or } 13-14 \text { on the } \\
\text { Borg scale. } \\
\text { Resistance exercise sets, } \\
\text { reps and intensity unclear }\end{array}$ & Unclear & $\begin{array}{l}\text { Refrain from any form of } \\
\text { recreational activity during } \\
\text { the study period }\end{array}$ \\
\hline Kim et al, 2006 & $\begin{array}{l}22,19 \text { (Intervention } \\
\text { vs control): } \mathrm{BCa}\end{array}$ & $\begin{array}{l}\text { Chemotherapy was the most } \\
\text { common type of adjuvant } \\
\text { therapy }(48.8 \%) \text {, followed by } \\
\text { radiotherapy }(34.1 \%) \text { and a } \\
\text { combination of } \\
\text { chemotherapy and } \\
\text { radiotherapy }(17.1 \%)\end{array}$ & $\begin{array}{l}\text { Aerobic exercise. } \\
\text { Frequency: three days per } \\
\text { week. Duration: } 30 \mathrm{~min} \text { of } \\
\text { aerobic exercise and five } \\
\text { minutes for warm-up or cool- } \\
\text { down. Intensity: moderate } \\
\text { intensity to produce an heart } \\
\text { rate corresponding to } \\
60-70 \% \text { of the individual's } \\
\text { heart rate reserve and/or } \mathrm{VO}_{2} \\
\text { peak achieved on a graded } \\
\text { exercise test at baseline }\end{array}$ & $\begin{array}{l}\text { Polar heart rate monitors and } \\
\text { a } 7 \text { day physical activity log }\end{array}$ & $\begin{array}{l}\text { Not to start any regular or } \\
\text { structured exercise } \\
\text { programme while } \\
\text { participating in the study }\end{array}$ \\
\hline Pinto et al, 2003 & $\begin{array}{l}12,12 \text { (Intervention } \\
\text { vs control): } \mathrm{BCa}\end{array}$ & Treatment completed & $\begin{array}{l}\text { Aerobic exercise. } \\
\text { Frequency: three times per } \\
\text { week. Duration: up to } 30 \mathrm{~min} \text {. } \\
\text { Intensity: } 60-70 \% \text { of peak } \\
\text { heart rate by the end of the } \\
\text { 12-week intervention }\end{array}$ & $\begin{array}{l}\text { Attendance at supervised } \\
\text { exercise sessions }\end{array}$ & $\begin{array}{l}\text { Not to change their current } \\
\text { level of physical activity }\end{array}$ \\
\hline Pinto et al, 2005 & $\begin{array}{l}\text { 43, } 43 \text { (Intervention } \\
\text { vs control): } \mathrm{BCa}\end{array}$ & $\begin{array}{l}49 \% \text { of intervention and } 74 \% \\
\text { of controls on hormone } \\
\text { therapy }\end{array}$ & $\begin{array}{l}\text { Aerobic exercise. } \\
\text { Frequency: } 2-5 \text { days per } \\
\text { week. Duration: } 10-30 \mathrm{~min} \text {. } \\
\text { Intensity: } 55-65 \% \text { of } \\
\text { maximum heart rate }\end{array}$ & $\begin{array}{l}\text { The } 7 \text { day physical activity } \\
\text { recall questionnaire and } \\
\text { accelerometer data providing } \\
\mathrm{kcal}^{-1}\end{array}$ & $\begin{array}{l}\text { Not to change their current } \\
\text { level of activity during the } \\
\text { first } 12 \text { weeks }\end{array}$ \\
\hline
\end{tabular}




\section{Table 1. (Continued)}

\begin{tabular}{|c|c|c|c|c|c|}
\hline Study & $\begin{array}{l}\mathbf{N} \text { and primary } \\
\text { cancer }\end{array}$ & Current treatment & $\begin{array}{l}\text { Exercise prescription } \\
\text { components }\end{array}$ & $\begin{array}{l}\text { Method of measuring } \\
\text { exercise behaviour }\end{array}$ & Instructions to controls \\
\hline Pinto et al, 2013 & $\begin{array}{l}\text { 20, } 26 \text { (Intervention } \\
\text { vs control): CRCa }\end{array}$ & Treatment completed & $\begin{array}{l}\text { Aerobic exercise. } \\
\text { Frequency: two to five times } \\
\text { per week. Duration: } \\
\text { 10-30 min. Intensity: } 64-76 \% \\
\text { of estimated maximum heart } \\
\text { rate }\end{array}$ & $\begin{array}{l}\text { The } 7 \text {-day physical activity } \\
\text { recall questionnaire; } \\
\text { community healthy activities } \\
\text { model programme for seniors } \\
\text { questionnaire; stage of } \\
\text { motivational readiness for } \\
\text { physical activity. } \\
\text { Accelerometer data }\end{array}$ & $\begin{array}{l}\text { Not to change their usual } \\
\text { level of activity }\end{array}$ \\
\hline Bourke et al, 2011a & $\begin{array}{l}9,9 \text { (Intervention vs } \\
\text { control): CRCa }\end{array}$ & Treatment completed & $\begin{array}{l}\text { Aerobic exercise. } \\
\text { Frequency: three times or } \\
\text { more per week. Duration: } \\
30 \text { min per session or more. } \\
\text { Intensity: } 55-85 \% \text { of age- } \\
\text { predicted maximum heart } \\
\text { rate/11-15 Borg scale. } \\
\text { Resistance exercise. } \\
\text { Frequency: three times per } \\
\text { week. Sets: between two and } \\
\text { four sets. Reps: eight to } 12 \\
\text { reps. Resistance exercise } \\
\text { intensity: } 60 \% \text { of one rep max }\end{array}$ & $\begin{array}{l}\text { Attendance at supervised } \\
\text { session with heart rate } \\
\text { monitors, exercise diaries and } \\
\text { Godin leisure score index } \\
\text { questionnaire }\end{array}$ & $\begin{array}{l}\text { Continue current exercise/ } \\
\text { dietary behaviours as } \\
\text { normal }\end{array}$ \\
\hline Bourke et al, 2011b & $\begin{array}{l}\text { 25, } 25 \text { (Intervention } \\
\text { vs control): PCa }\end{array}$ & $\begin{array}{l}\text { Undergoing androgen } \\
\text { suppression therapy for a } \\
\text { minimum of } 6 \text { months prior }\end{array}$ & $\begin{array}{l}\text { Aerobic exercise. } \\
\text { Frequency: three times per } \\
\text { week. Duration: } 30 \text { min } \\
\text { per session or more. } \\
\text { Intensity: } 55-85 \% \text { of age- } \\
\text { predicted maximum heart } \\
\text { rate/11-15 Borg scale. } \\
\text { Resistance exercise. } \\
\text { Frequency: three times per } \\
\text { week. Sets: between two and } \\
\text { four sets. Reps: eight to } 12 \\
\text { reps. Intensity: } 60 \% \text { of } 1 \text { rep } \\
\text { max }\end{array}$ & $\begin{array}{l}\text { Attendance at supervised } \\
\text { session with heart rate } \\
\text { monitors, exercise diaries and } \\
\text { Godin leisure score index } \\
\text { questionnaire }\end{array}$ & $\begin{array}{l}\text { Continue current exercise/ } \\
\text { dietary behaviours as } \\
\text { normal }\end{array}$ \\
\hline Hayes et al, 2009 & $\begin{array}{l}\text { 16, } 16 \text { (Intervention } \\
\text { vs control): } \mathrm{BCa}\end{array}$ & Treatment completed & $\begin{array}{l}\text { Aerobic exercise. } \\
\text { Frequency: three to four or } \\
\text { more times per week. } \\
\text { Duration: } 20-45+\text { min. } \\
\text { Intensity: three to seven on a } \\
\text { modified Borg scale. } \\
\text { Resistance exercise sets } \\
\text { unclear }\end{array}$ & $\begin{array}{l}\text { Exercise adherence rates and } \\
\text { qualitative comments were } \\
\text { used to provide insight into } \\
\text { the acceptability of the } \\
\text { programme }\end{array}$ & Continue habitual activities \\
\hline $\begin{array}{l}\text { McKenzie and } \\
\text { Kalda, } 2003\end{array}$ & $\begin{array}{l}\text { 7,7 (Intervention vs } \\
\text { control): BCa }\end{array}$ & Treatment completed & $\begin{array}{l}\text { Aerobic exercise. } \\
\text { Frequency: } 3 \text { days per week } \\
\text { (initiated after week 2). } \\
\text { Duration: } 5-20 \text { min. Intensity: } \\
\text { arm cycling at a resistance of } \\
8.3-25 \mathrm{~W} \text {. Intensity was also } \\
\text { assessed with Polar HR } \\
\text { monitors. A target heart rate } \\
\text { was } 60-80 \% \text { of maximum } \\
\text { predicted by age. } \\
\text { Resistance exercise intensity } \\
\text { unclear }\end{array}$ & $\begin{array}{l}\text { Work in kJ was calculated for } \\
\text { each session for every } \\
\text { subject, and this was used to } \\
\text { calculate cumulative work } \\
\text { performed over the course of } \\
\text { the programme }\end{array}$ & $\begin{array}{l}\text { Not to initiate any new } \\
\text { activity }\end{array}$ \\
\hline Musanti, 2012 & $\begin{array}{l}\text { Flexibility group } \\
(n=13) ; \text { aerobic } \\
\text { group ( } n=12) \\
\text { resistance group } \\
(n=17) \text {, aerobic } \\
\text { and resistance } \\
\text { group ( } n=13): B C a\end{array}$ & $\begin{array}{l}\text { Hormonal therapy could be } \\
\text { on-going: } 56 \% \text { on hormone } \\
\text { therapy }\end{array}$ & $\begin{array}{l}\text { Aerobic exercise. } \\
\text { Frequency: three to five } \\
\text { times per week. Duration: } \\
15-30 \text { min. Intensity: } 40-65 \% \\
\text { of the calculated maximum } \\
\text { heart rate. } \\
\text { Resistance exercise. } \\
\text { Frequency: } 2 / 3 \text { times per } \\
\text { week reps: } 10-12 \text {. Resistance } \\
\text { exercise sets: one. Intensity: } \\
\text { rating of perceived exertion } \\
\text { of three to eight, on a scale of } \\
\text { one to } 10\end{array}$ & $\begin{array}{l}\text { Adherence to the exercise } \\
\text { prescription was calculated as } \\
\text { a proportion of completed } \\
\text { sessions over the total } \\
\text { possible number of sessions } \\
\text { in their assigned exercise } \\
\text { programme }\end{array}$ & $\begin{array}{l}\text { All participants were } \\
\text { prescribed flexibility } \\
\text { exercise and received a } \\
\text { written guidebook that } \\
\text { included general } \\
\text { information about exercise } \\
\text { participation, an } \\
\text { individualised exercise } \\
\text { prescription, exercise } \\
\text { instructions and an exercise } \\
\text { log sheet }\end{array}$ \\
\hline
\end{tabular}




\begin{tabular}{|c|c|c|c|c|c|}
\hline Study & $\begin{array}{l}\mathrm{N} \text { and primary } \\
\text { cancer }\end{array}$ & Current treatment & $\begin{array}{l}\text { Exercise prescription } \\
\text { components }\end{array}$ & $\begin{array}{l}\text { Method of measuring } \\
\text { exercise behaviour }\end{array}$ & Instructions to controls \\
\hline Perna et al, 2010 & $\begin{array}{l}51 \text { Participants in } \\
\text { total. Numbers } \\
\text { randomised to } \\
\text { each arm are } \\
\text { unclear: } \mathrm{BCa}\end{array}$ & $\begin{array}{l}\text { The majority (52.9\%) of } \\
\text { women had stage I breast } \\
\text { cancer and received } \\
\text { lumpectomy surgery (74.1\%). } \\
\text { Many (44.1\%) women } \\
\text { received both radiation and } \\
\text { chemotherapy, } 26.5 \% \\
\text { received radiation only, } 8.8 \% \\
\text { received chemotherapy only, } \\
\text { and } 20.6 \% \text { received no } \\
\text { adjuvant therapy }\end{array}$ & $\begin{array}{l}\text { Aerobic exercise. } \\
\text { Frequency: three or more } \\
\text { times per week. Duration: } \\
\text { 15-45 min. Intensity: } 50-85 \% \\
\text { of maximum predicted heart } \\
\text { rate or } 11-16 \text { on the Borg } \\
\text { scale. } \\
\text { Resistance exercise. } \\
\text { Frequency: three times per } \\
\text { week. Sets: one to two sets. } \\
\text { Resistance exercise reps: } \\
\text { 12-15. Participant body } \\
\text { weight was used for lower } \\
\text { body exercises }\end{array}$ & $\begin{array}{l}\text { Participants were provided } \\
\text { with monthly calendars to } \\
\text { record their exercise activity } \\
\text { and were contacted weekly } \\
\text { by telephone or electronic } \\
\text { mail according to patient } \\
\text { preference. Godin leisure } \\
\text { score index and the leisure } \\
\text { time exercise questionnaire } \\
\text { self-report instrument surveys } \\
\text { were also used }\end{array}$ & $\begin{array}{l}\text { Women in the information } \\
\text { control group received a } \\
45 \text { min session covering } \\
\text { their fitness, strength and } \\
\text { flexibility assessment results } \\
\text { and an informational } \\
\text { brochure }\end{array}$ \\
\hline
\end{tabular}

study regarding the promotion of aerobic exercise behaviour, with $75 \%$ of the intervention group reporting between 90 and 119 min per week of moderate intensity exercise, at an average heart rate of $76 \%$ of predicted maximum, for 6 months. However, of these three trials, only two (Bourke et al, 2011a, b) met the Rock et al (2012) exercise guidelines: specifically, two to four sets of resistance exercise at $60 \%$ of one rep maximum, for eight to 12 reps, was carried out twice per week, for just 6 weeks. These three trials shared the following BCTs: goal setting, self-monitoring of behaviour and prompting practice, which were common to most of the interventions, included in the review; however, additionally these three studies included generalisation of a target behaviour that is, getting people to engage in exercise outside of the immediate intervention environment.

These trials did not explicitly state a theoretical basis. Other studies such as Daley et al (2007) or Perna et al (2010) were much more comprehensive in their reporting of BCTs and were based on recognised behaviour-change theory. Full details of intervention coding according to the CALO-RE taxonomy (Michie et al, 2011) of exercise BCTs can be seen in Table 3. Several trials might have achieved an adherence of $75 \%$ or more; however, because of unclear reporting it was not possible to make a judgement on whether this criterion had been fulfilled.

A meta-analysis of change in aerobic exercise tolerance was carried out on seven trials that reported these outcomes. Aerobic exercise tolerance was significantly better after 8-12 weeks of follow-up in intervention $v s$ control in 330 participants $(\mathrm{SMD}=0.73,95 \% \mathrm{CI}=0.51-0.95)$ and at 6 months of follow-up in intervention $v s$ control in 271 participants $(\mathrm{SMD}=0.70,95 \%$ $\mathrm{CI}=0.45,0.94$; see Figure 2). The 6-month data should be viewed with caution as four of the five trials were judged to have a high risk of bias. Limb strength was significantly better in intervention $v s$ controls in 91 participants (SMD $=0.51,95 \%$ $\mathrm{CI}=0.09-0.93$ ). After removing one trial for a high risk of bias (Musanti, 2012), in 68 participants the moderate effect size was still apparent but was no longer significant ( $\mathrm{SMD}=0.47,95 \%$ $\mathrm{CI}=-0.01,0.96)$.

Attrition rates during the intervention from the included trials ranged from 25\% (Pinto et al, 2003) to 0\% (Drouin et al, 2005) (median 6\%), with five trials not clearly reporting attrition in the intervention arm. Eight trials reported adverse events that ranged from minor - for example, muscular-skeletal problems (Musanti, 2012) to major events - for example, death (Kim et al, 2006). However, only one study was explicit as to which of these adverse events were caused by participating in the intervention group (two instances of plantar fasciitis; Cadmus et al, 2009).

\section{DISCUSSION}

The review findings indicate that currently there is a lack of convincing evidence to suggest that existing exercise interventions are useful for achieving the Rock et al (2012) guidelines of $150 \mathrm{~min}$ per week of aerobic exercise and twice per week of resistance exercise, in sedentary cancer cohorts. Adherence to exercise interventions, which is crucial for understanding treatment dose, is frequently poorly reported. Importantly, the fundamental metrics of exercise behaviour, that is, frequency, intensity and duration, or repetitions, sets and intensity of resistance training, although easy to devise and report, are seldom included in published clinical trials. Attempting to reproduce any exercise prescription without detailing these metrics is fraught with problems, and most likely not possible. The extent of exclusion at the full-text screening stage (377 publications excluded from 402) provided the first indication of problems associated with quality of reporting in this research field.

The supportive evidence that we have narratively synthesised suggests that interventions that combine the supervision of exercise training in tandem with a requirement of independent exercise are likely to promote better adherence. Use of generalisation of behaviour was also a common and relatively unique feature of interventions, which reported better adherence.

Despite the uncertainty around adherence in many of the included trials, the interventions caused improvements in aerobic exercise tolerance at 8-12 weeks and 6 months of follow-up.

Such improvements could be interpreted as reassuring: some of the doubts around adherence might only extend to reporting issues rather than real problems with fidelity. Alternatively, this result could have arisen from the rapid, relatively large early gains in function expected in sedentary participants from exercise training, which could mask smaller changes in non-adherers. Further, aerobic exercise tolerance should not be considered as definitive evidence of changes in aerobic fitness (with the accompanying spectrum of underlying physiological adaptation). It could simply reflect individuals becoming accustomed to the feeling of exertion from exercise testing and a better tolerance towards perceptions of fatigue.

To the authors' knowledge, this is the first comprehensive review to evaluate RCTs with respect to their success in improving exercise behaviour in sedentary cancer cohorts against state of the art recommendations for these patients. The large majority of these trials included women with breast cancer, the remaining three were in people with prostate and colorectal cancer. Furthermore, the 
Table 2. Summary of study exercise behaviour

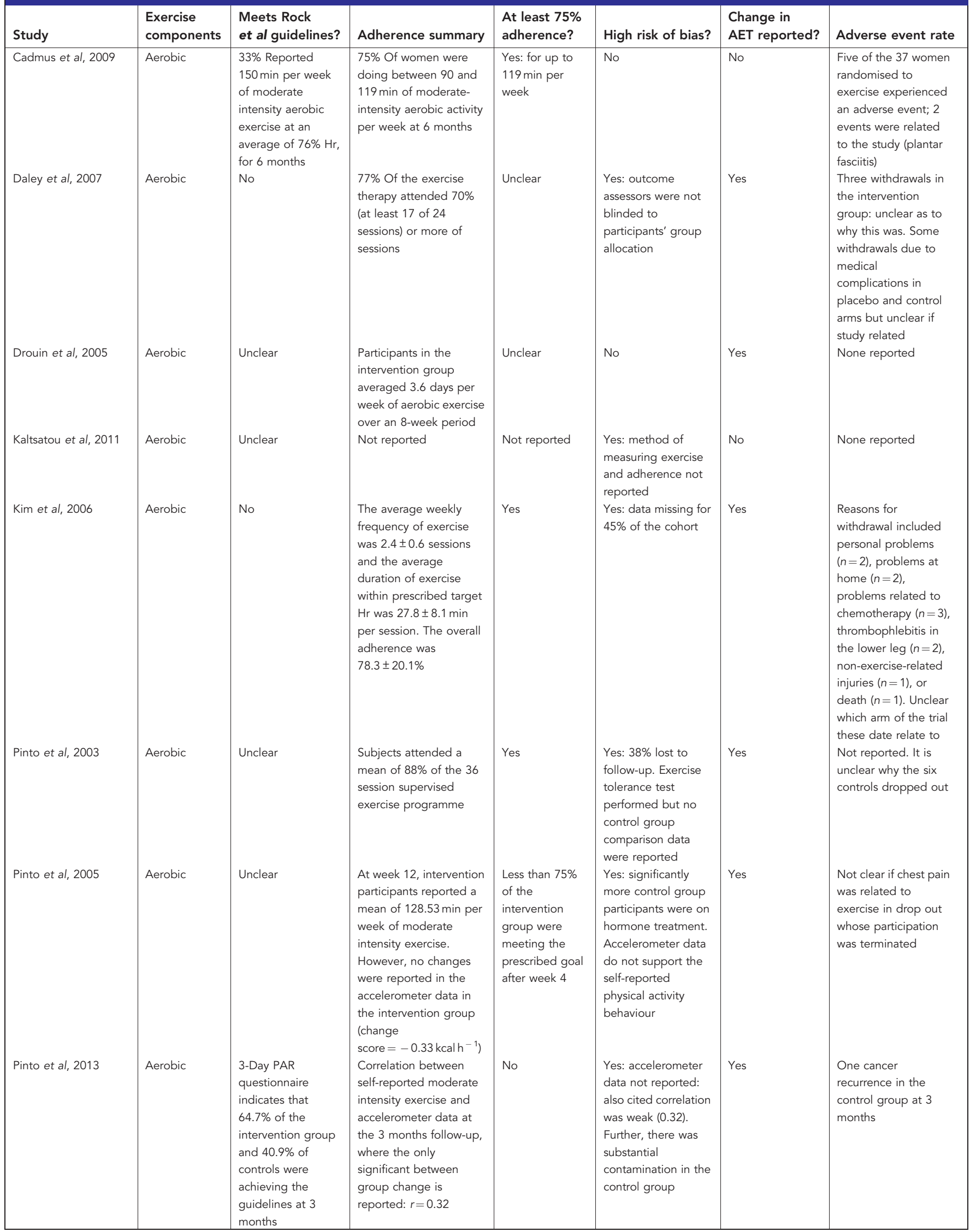




\section{Table 2. (Continued)}

\begin{tabular}{|c|c|c|c|c|c|c|c|}
\hline Study & $\begin{array}{l}\text { Exercise } \\
\text { components }\end{array}$ & $\begin{array}{l}\text { Meets Rock } \\
\text { et al guidelines? }\end{array}$ & Adherence summary & $\begin{array}{l}\text { At least } 75 \% \\
\text { adherence? }\end{array}$ & High risk of bias? & $\begin{array}{l}\text { Change in } \\
\text { AET reported? }\end{array}$ & Adverse event rate \\
\hline Bourke et al, 2011a & $\begin{array}{l}\text { Aerobic and } \\
\text { resistance }\end{array}$ & $\begin{array}{l}6 \text { Weeks of } \\
\text { resistance exercise } \\
\text { at twice a week }\end{array}$ & $\begin{array}{l}90 \% \text { Attendance at the } \\
\text { supervised sessions. } \\
94 \% \text { of the independent } \\
\text { exercise sessions were } \\
\text { completed }\end{array}$ & Yes & No & Yes & $\begin{array}{l}\text { One stroke in the } \\
\text { intervention group, } \\
\text { unrelated to the } \\
\text { exercise programme }\end{array}$ \\
\hline Bourke et al, 2011b & $\begin{array}{l}\text { Aerobic and } \\
\text { resistance }\end{array}$ & $\begin{array}{l}6 \text { Weeks of } \\
\text { resistance exercise } \\
\text { at twice a week. }\end{array}$ & $\begin{array}{l}95 \% \text { Attendance at the } \\
\text { supervised exercise } \\
\text { sessions. Compliance to } \\
\text { the self-directed } \\
\text { exercise aspect of the } \\
\text { lifestyle intervention was } \\
87 \%\end{array}$ & Yes & $\begin{array}{l}\text { Yes: high dropout } \\
\text { rate at the post } \\
\text { intervention } 6 \text { month } \\
\text { follow-up } \\
\text { assessment }\end{array}$ & Yes & $\begin{array}{l}\text { Two men in the } \\
\text { intervention arm were } \\
\text { discontinued due to } \\
\text { cardiac complications } \\
\text { before the } 12 \text { week } \\
\text { assessments. Two } \\
\text { more reported } \\
\text { muscular-skeletal } \\
\text { complaints before the } \\
6 \text { month assessment. } \\
\text { Five men reported } \\
\text { various health } \\
\text { problems in the } \\
\text { control group } \\
\text { prohibiting them } \\
\text { attending the } \\
6 \text { month assessment }\end{array}$ \\
\hline Hayes et al, 2009 & $\begin{array}{l}\text { Aerobic and } \\
\text { resistance }\end{array}$ & Unclear & $\begin{array}{l}\text { The majority of women } \\
\text { ( } 88 \% \text { ) allocated to the } \\
\text { intervention group } \\
\text { participated in } 70 \% \text { or } \\
\text { more of scheduled } \\
\text { supervised exercise } \\
\text { sessions }\end{array}$ & Unclear & $\begin{array}{l}\text { Yes: adherence data } \\
\text { on unsupervised } \\
\text { aspect of the } \\
\text { intervention is not } \\
\text { clear }\end{array}$ & No & None reported \\
\hline $\begin{array}{l}\text { McKenzie and } \\
\text { Kalda, } 2003\end{array}$ & $\begin{array}{l}\text { Aerobic and } \\
\text { resistance }\end{array}$ & No & Unclear & Unclear & $\begin{array}{l}\text { Yes: adherence to } \\
\text { exercise not } \\
\text { reported }\end{array}$ & No & None reported \\
\hline Musanti 2012 & $\begin{array}{l}\text { Aerobic and } \\
\text { resistance }\end{array}$ & $\begin{array}{l}12 \text { Weeks of } \\
\text { resistance exercise } \\
\text { at twice or three } \\
\text { times per week }\end{array}$ & $\begin{array}{l}\text { Mean percentage } \\
\text { adherence were as } \\
\text { follows: flexibility }=85 \% \text {, } \\
\text { aerobic }=81 \% \text {, } \\
\text { resistance }=91 \% \text {, and } \\
\text { aerobic plus } \\
\text { resistance }=86 \%\end{array}$ & 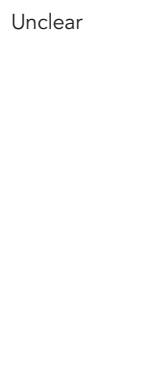 & $\begin{array}{l}\text { Yes: a significant } \\
\text { number of the } \\
\text { dropouts belonged } \\
\text { to the resistance } \\
\text { exercise group } \\
\text { ( } n=8 / 13) \text {. Only } 50 \% \\
\text { of activity logs } \\
\text { returned }\end{array}$ & Yes & $\begin{array}{l}\text { There were adverse } \\
\text { events reported in } \\
\text { two women during } \\
\text { the study. In both } \\
\text { cases, the women } \\
\text { developed tendinitis: } \\
\text { one in the shoulder } \\
\text { and the other in the } \\
\text { foot. Both had } \\
\text { histories of tendonitis, } \\
\text { and both received } \\
\text { standard treatment }\end{array}$ \\
\hline Perna et al, 2010 & $\begin{array}{l}\text { Aerobic and } \\
\text { resistance }\end{array}$ & $\begin{array}{l}\text { Three months of } \\
\text { resistance exercise } \\
\text { at three times per } \\
\text { week }\end{array}$ & $\begin{array}{l}\text { Women assigned to the } \\
\text { structured intervention } \\
\text { completed an average } \\
\text { of } 83 \% \text { of their } \\
\text { scheduled hospital- } \\
\text { based exercise sessions, } \\
\text { (only } 4 \text { weeks in } \\
\text { duration) and } 76.9 \% \\
\text { completed all } 12 \\
\text { sessions. Home-based } \\
\text { component (8 weeks in } \\
\text { duration not clear) }\end{array}$ & Unclear & $\begin{array}{l}\text { Yes: numbers } \\
\text { randomised to } \\
\text { intervention and } \\
\text { control groups are } \\
\text { unclear as are } \\
\text { numbers completing } \\
\text { in each arm }\end{array}$ & No & Unclear \\
\hline
\end{tabular}

overwhelming majority of participants were White, with only one trial made up of an ethnically diverse population. As such, other ethnicities are substantially under-represented. Thirteen of the 14 included trials were conducted in North America or Western Europe, with one trial from Australia. All were in high-income nations. No evidence was found from low- or middle-income countries, and it is uncertain whether the featured interventions would be deliverable in these parts of the world.

Another recent systematic review that examined predictors of adherence to exercise in people living with and beyond cancer
(Husebo et al, 2013) found that the transtheoretical model of behaviour change and the theory of planned behaviour were significantly associated with better exercise adherence. The current review does not explicitly support such conclusions. It should be noted that there are key differences in each review methodology, with the present review only including RCTs and people who were sedentary at baseline. Other recent systematic reviews have focused on the potential health-related outcomes of exercise interventions for people living with and beyond cancer. In this respect, Fong et al (2012) similarly reported improvements in aerobic exercise 
Table 3. CALO-RE taxonomy of behaviour-change techniques

\begin{tabular}{|c|c|c|c|c|c|c|c|c|c|c|c|c|c|c|}
\hline $\begin{array}{l}\text { Behaviour change } \\
\text { technique }\end{array}$ & $\begin{array}{c}\text { Bourke } \\
\text { et al, } \\
\text { 2011a }\end{array}$ & $\begin{array}{l}\text { Bourke } \\
\text { et al, } \\
2011 \mathrm{~b}\end{array}$ & $\begin{array}{l}\text { Cadmus } \\
\text { et al, } \\
2009\end{array}$ & $\begin{array}{l}\text { Daley } \\
\text { et al, } \\
2007\end{array}$ & $\begin{array}{l}\text { Drouin } \\
\text { et al, } \\
2005\end{array}$ & $\begin{array}{l}\text { Hayes } \\
\text { et al, } \\
2009\end{array}$ & $\begin{array}{l}\text { Kaltsatou } \\
\text { et al, } \\
2011\end{array}$ & $\begin{array}{c}\text { McKenzie } \\
\text { and } \\
\text { Kalda, } \\
2003\end{array}$ & $\begin{array}{c}\text { Musanti, } \\
2012\end{array}$ & $\begin{array}{l}\text { Perna } \\
\text { et al, } \\
2010\end{array}$ & $\begin{array}{l}\text { Kim } \\
\text { et al, } \\
2006\end{array}$ & $\begin{array}{l}\text { Pinto } \\
\text { et al, } \\
2003\end{array}$ & $\begin{array}{l}\text { Pinto } \\
\text { et al, } \\
2005\end{array}$ & $\begin{array}{l}\text { Pinto } \\
\text { et al, } \\
2013\end{array}$ \\
\hline Theory & & & & TTM & & & & & EXSEM & TTM & & & TTM & $\begin{array}{l}\text { TTM } \\
\text { SCT }\end{array}$ \\
\hline $\begin{array}{l}\text { Provide Info on } \\
\text { consequences of behaviour } \\
\text { in general }\end{array}$ & & & $x$ & $x$ & & & & & & $x$ & $x$ & & & \\
\hline \multicolumn{15}{|l|}{$\begin{array}{l}\text { Provide Info on } \\
\text { consequences of behaviour } \\
\text { to the individual }\end{array}$} \\
\hline \multicolumn{15}{|l|}{$\begin{array}{l}\text { Provide Info about others } \\
\text { approval }\end{array}$} \\
\hline \multicolumn{15}{|l|}{$\begin{array}{l}\text { Provide normative info } \\
\text { about others behaviour }\end{array}$} \\
\hline Programme set goal & $\mathrm{x}$ & $\mathrm{x}$ & $\mathrm{x}$ & $x$ & $\mathrm{x}$ & $x$ & $x$ & $\mathrm{x}$ & $\mathrm{x}$ & $\mathrm{x}$ & $\mathrm{x}$ & $\mathrm{x}$ & $\mathrm{x}$ & $\mathrm{x}$ \\
\hline Goal-setting (behaviour) & & & $\mathrm{x}$ & $x$ & & & & & & $x$ & & $x$ & $x$ & $x$ \\
\hline \multicolumn{15}{|l|}{ Goal setting (outcome) } \\
\hline \multicolumn{15}{|l|}{ Action planning } \\
\hline $\begin{array}{l}\text { Barrier identification/ } \\
\text { problem solving }\end{array}$ & & $x$ & $x$ & $x$ & & & & & & $x$ & & & $x$ & $x$ \\
\hline Set graded tasks & & & $x$ & $x$ & & $\mathrm{x}$ & $\mathrm{x}$ & $\mathrm{x}$ & $\mathrm{x}$ & $\mathrm{x}$ & & $\mathrm{x}$ & & $\mathrm{x}$ \\
\hline $\begin{array}{l}\text { Prompt review of } \\
\text { behavioural goals }\end{array}$ & & & & $x$ & & & & & & $x$ & & & & \\
\hline \multicolumn{15}{|l|}{$\begin{array}{l}\text { Prompt review of outcome } \\
\text { goals }\end{array}$} \\
\hline $\begin{array}{l}\text { Prompt rewards contingent } \\
\text { on effort or progress } \\
\text { towards goal }\end{array}$ & & & & & & & & & & $x$ & & & $x$ & $x$ \\
\hline $\begin{array}{l}\text { Provide rewards contingent } \\
\text { on successful behaviour }\end{array}$ & & & & $x$ & & & & & & & & & & \\
\hline \multicolumn{15}{|l|}{ Shaping } \\
\hline $\begin{array}{l}\text { Prompting generalisation } \\
\text { of a target behaviour }\end{array}$ & $x$ & $x$ & $x$ & & & & & & & $x$ & & $x$ & & \\
\hline $\begin{array}{l}\text { Prompt self-monitoring of } \\
\text { behaviour }\end{array}$ & $x$ & $x$ & $x$ & $x$ & $x$ & & & & $x$ & $x$ & & $x$ & $x$ & $x$ \\
\hline $\begin{array}{l}\text { Prompt self-monitoring of } \\
\text { behavioural outcome }\end{array}$ & & & $x$ & $x$ & $x$ & & & & $x$ & & & & $x$ & $x$ \\
\hline $\begin{array}{l}\text { Prompting focus on past } \\
\text { success }\end{array}$ & & & & $\mathrm{x}$ & & & & & & & & & & \\
\hline $\begin{array}{l}\text { Provide feedback on } \\
\text { performance }\end{array}$ & & & $x$ & & & & & & & $x$ & & & $x$ & $x$ \\
\hline $\begin{array}{l}\text { Provide information on } \\
\text { where and when to perform } \\
\text { behaviour }\end{array}$ & & & & $\mathrm{x}$ & & & & & & $x$ & & & & \\
\hline $\begin{array}{l}\text { Provide instruction on how } \\
\text { to perform the behaviour }\end{array}$ & & $\mathrm{x}$ & $\mathrm{x}$ & $x$ & $x$ & & $x$ & & $x$ & $x$ & $x$ & $x$ & & $x$ \\
\hline $\begin{array}{l}\text { Model/demonstrate the } \\
\text { behaviour }\end{array}$ & & & & & & & $x$ & & $x$ & $x$ & & & & \\
\hline Teach to use prompts/cues & & & & $x$ & & & & & & $x$ & & & & $x$ \\
\hline Environmental restructuring & & & & & & & & & & $x$ & & & & $x$ \\
\hline Agree behavioural contract & & & & & & & & & & $x$ & & & & \\
\hline Prompt practice & $x$ & $x$ & $x$ & $x$ & $\mathrm{x}$ & $x$ & $x$ & $x$ & $x$ & $x$ & $x$ & $x$ & $x$ & $\mathrm{x}$ \\
\hline Use of follow-up prompts & $x$ & $x$ & & & & & & & & & & & & \\
\hline \multicolumn{15}{|l|}{ Facilitate social comparison } \\
\hline $\begin{array}{l}\text { Plan social support/social } \\
\text { change }\end{array}$ & & & $\mathrm{x}$ & $x$ & & & & & & $x$ & & & & \\
\hline \multicolumn{15}{|l|}{$\begin{array}{l}\text { Prompt identification as } \\
\text { role model/position } \\
\text { advocate }\end{array}$} \\
\hline \multicolumn{15}{|l|}{ Prompt anticipated regret } \\
\hline \multicolumn{15}{|l|}{ Fear arousal } \\
\hline Prompt self-talk & & & & & & & & & & & & & & \\
\hline
\end{tabular}


Table 3. (Continued)

\begin{tabular}{|c|c|c|c|c|c|c|c|c|c|c|c|c|c|c|}
\hline $\begin{array}{l}\text { Behaviour change } \\
\text { technique }\end{array}$ & $\begin{array}{c}\text { Bourke } \\
\text { et al, } \\
2011 \text { a }\end{array}$ & $\begin{array}{c}\text { Bourke } \\
\text { et al, } \\
2011 \mathrm{~b}\end{array}$ & $\begin{array}{c}\text { Cadmus } \\
\text { et al, } \\
2009\end{array}$ & $\begin{array}{l}\text { Daley } \\
\text { et al, } \\
2007\end{array}$ & $\begin{array}{c}\text { Drouin } \\
\text { et al, } \\
2005\end{array}$ & $\begin{array}{l}\text { Hayes } \\
\text { et al, } \\
2009\end{array}$ & $\begin{array}{l}\text { Kaltsatou } \\
\text { et al, } \\
2011\end{array}$ & $\begin{array}{c}\text { McKenzie } \\
\text { and } \\
\text { Kalda, } \\
2003\end{array}$ & $\begin{array}{c}\text { Musanti, } \\
2012\end{array}$ & $\begin{array}{l}\text { Perna } \\
\text { et al, } \\
2010\end{array}$ & $\begin{array}{l}\text { Kim } \\
\text { et al, } \\
2006\end{array}$ & $\begin{array}{l}\text { Pinto } \\
\text { et al, } \\
2003\end{array}$ & $\begin{array}{l}\text { Pinto } \\
\text { et al, } \\
2005\end{array}$ & $\begin{array}{l}\text { Pinto } \\
\text { et al, } \\
2013\end{array}$ \\
\hline Theory & & & & TTM & & & & & EXSEM & TTM & & & TTM & $\begin{array}{l}\text { TTM } \\
\text { SCT }\end{array}$ \\
\hline \multicolumn{15}{|l|}{ Prompt use of imagery } \\
\hline $\begin{array}{l}\text { Relapse prevention/coping } \\
\text { planning }\end{array}$ & & & & $x$ & & & & & & $x$ & & & & \\
\hline $\begin{array}{l}\text { Stress management/ } \\
\text { emotional control training }\end{array}$ & & & & & & & & & & & $x$ & & & \\
\hline \multicolumn{15}{|l|}{ Motivational interviewing } \\
\hline \multicolumn{15}{|l|}{ Time management } \\
\hline \multicolumn{15}{|l|}{$\begin{array}{l}\text { General communication } \\
\text { skills training }\end{array}$} \\
\hline $\begin{array}{l}\text { Stimulate anticipation of } \\
\text { future rewards }\end{array}$ & & & & & & & & & & & & & & \\
\hline
\end{tabular}

\section{A}

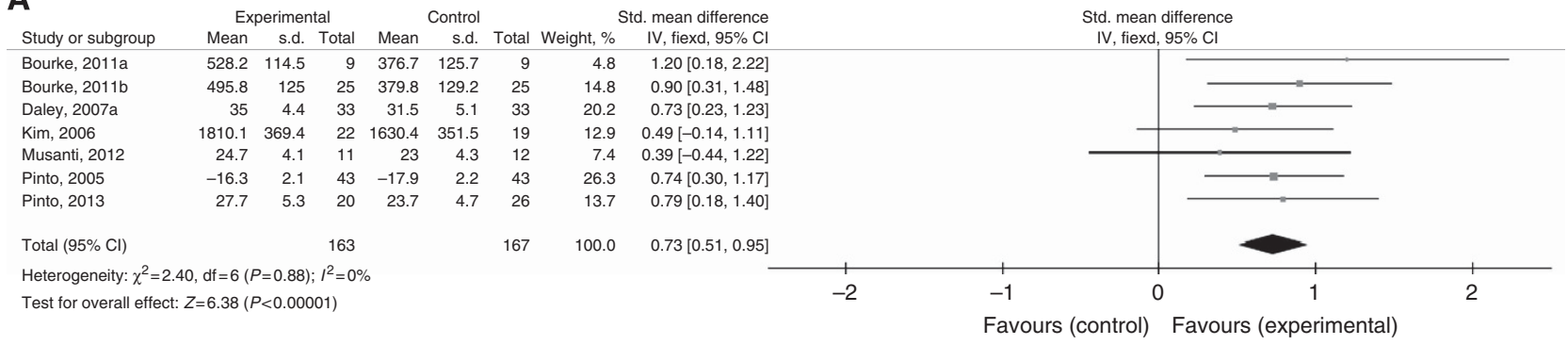

B

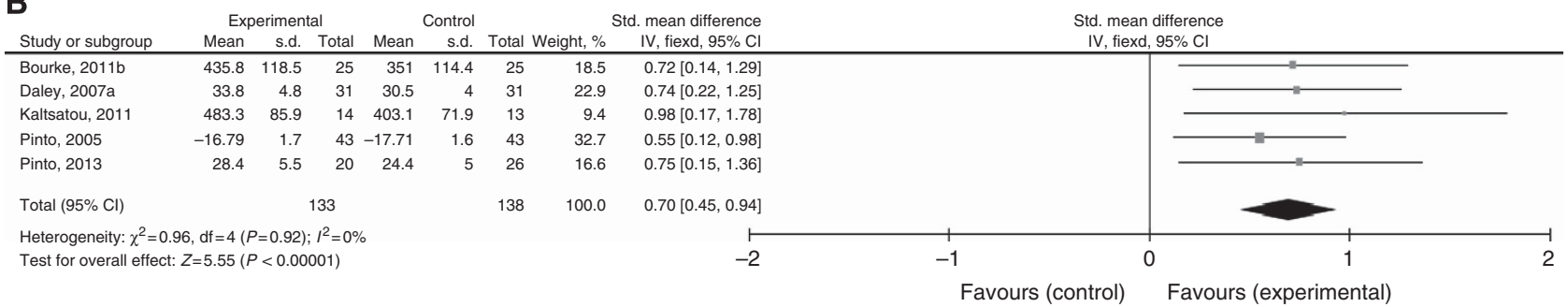

Figure 2. Meta-analysis of (A) aerobic exercise tolerance at 8-12 weeks of follow-up and (B) aerobic exercise tolerance at 6 months of follow-up. Note, in all meta-analysis data from Pinto et al (2005) has been multiplied by -1 to control for direction of effect (that is, lower values in a timed test indicate a better outcome). Data were extracted from the combined aerobic and resistance training arm of Musanti (2012).

tolerance and muscle strength. One substantial difference in the methodology of the present review when compared with other Cochrane reviews in the area (Mishra et al, 2012a, b) is that we only included studies where the essential metrics of exercise behaviour are reported.

There are limitations to this review, namely the large majority of these trials included women with breast cancer. One trial involved men with advanced prostate cancer and two trials involved colorectal cancer survivors. Although these three primary cancers make up the majority of the population living with and beyond cancer, other common cancers such as lymphoma and lung cancer do not appear at all in this review. Less common cancers are also not represented in the evidence base. Furthermore, the overwhelming majority of participants were White, with only one trial made up of an ethnically diverse population.

Recently, in the largest survey of cancer survivors (covering multiple cancer types) to be conducted in Europe $(N=3300)$, the UK Department of Health reported that $<25 \%$ of people living with and beyond cancer are achieving $30 \mathrm{~min}$ of exercise on 5 or more days per week. (Department of Health-Quality Health, 2012) This is a clear indicator that the overwhelming majority of cancer survivors are not active. It is therefore of critical importance that future research is designed to improve exercise behaviour in sedentary individuals living with or beyond cancer, particularly in under-represented groups. All trials should report as standard, frequency, intensity and duration of aerobic exercise, as well as reps, sets and intensity of resistance exercise used in intervention prescriptions. Using these essential metrics of exercise prescription will not only help to achieve a balance between safe yet effective exercise but will also ensure that meaningful re-evaluation over time can be undertaken, as adaptation or disease progression dictates.

Reporting of adherence as a single proportion of the cohort who attended/performed exercise according to the set prescription and reporting of BCTs (e.g., using the CALO-RE taxonomy) needs to be standardised. By achieving these standardisations, oncology 
scientists and clinicians will help to bring the discipline up to the level of acceptable rigour that will help to elucidate dose response of exercise interventions for given health outcomes. This should afford an opportunity to communicate achievable exercise recommendations for sedentary people living with and beyond cancer.

\section{DISCLAIMER}

This review received no external funding.

\section{REFERENCES}

Bourke L, Doll H, Crank H, Daley A, Rosario D, Saxton JM (2011a) Lifestyle intervention in men with advanced prostate cancer receiving androgen suppression therapy: a feasibility study. Cancer Epidemiol Biomarkers Prev 20(4): 647-657.

Bourke L, Homer K, Thaha M, Steed E, Rosario J, Robb K, Saxton J, Taylor S (2013) Interventions for promoting habitual exercise in people living with and beyond cancer. Cochrane Database Syst Rev (9): CD010192.

Bourke L, Thompson G, Gibson DJ, Daley A, Crank H, Adam I, Shorthouse A, Saxton J (2011b) Pragmatic lifestyle intervention in patients recovering from colon cancer: a randomized controlled pilot study. Arch Phys Med Rehabil 92(5): 749-755.

Cadmus LA, Salovey P, Yu H, Chung G, Kasl S, Irwin ML (2009) Exercise and quality of life during and after treatment for breast cancer: results of two randomized controlled trials. Psychooncology 18(4): 343-352.

Cochrane IMS. RevMan 5.2 software http://ims.cochrane.org/revman/ download (accessed 01 March 2013).

Daley AJ, Crank H, Saxton JM, Mutrie N, Coleman R, Roalfe A (2007) Randomized trial of exercise therapy in women treated for breast cancer. J Clin Oncol 25(13): 1713-1721.

Department of Health - Quality Health (2012) Quality of Life of Cancer Survivors in England: Report on a pilot survey using Patient Reported Outcome Measures (PROMS). Available at https://www.wp.dh.gov.uk/ publications/files/2012/12/9284-TSO-2900701-PROMS.pdf.

Drouin JS, Armstrong H, Krause S, Orr J, Birk TJ, Hryniuk WM, LE H (2005) Effects of aerobic exercise training on peak aerobic capacity, fatigue, and psychological factors during radiation for breast cancer. Rehabil Oncol 23: 11-17.

Elliott J, Fallows A, Staetsky L, Smith PW, Foster CL, Maher EJ, Corner J (2011) The health and well-being of cancer survivors in the UK: findings from a population-based survey. Br J Cancer 105(Suppl 1): S11-S20.

Ferrell BR, Grant M, Funk B, Otis-Green S, Garcia N (1998) Quality of life in breast cancer. Part II: psychological and spiritual well-being. Cancer Nurs 21(1): 1-9.

Fong DY, Ho JW, Hui BP, Lee AM, Macfarlane DJ, Leung SS, Cerin E, Chan WY, Leung IP, Lam SH, Taylor AJ, Cheng KK (2012) Physical activity for cancer survivors: meta-analysis of randomised controlled trials. BMJ 344: e70.

GLOBOCAN (2008) Estimated age-standardised incidence and mortality rates: both sexes. Available at http://globocan.iarc.fr/factsheet.asp (accessed 10 September 2013).

Hayes SC, Reul-Hirche H, Turner J (2009) Exercise and secondary lymphedema: safety, potential benefits, and research issues. Med Sci Sport Exer 41(3): 483-489.

Higgins JPT, Green S (eds). (2011) Cochrane Handbook for Systematic Reviews of Interventions Version 5.1.0 (Updated March 2011). The Cochrane Collaboration.

Holmes MD, Chen WY, Feskanich D, Kroenke CH, Colditz GA (2005) Physical activity and survival after breast cancer diagnosis. JAMA 293(20): 2479-2486.

Husebo AM, Dyrstad SM, Soreide JA, Bru E (2013) Predicting exercise adherence in cancer patients and survivors: a systematic review and metaanalysis of motivational and behavioural factors. J Clin Nurs 22 (1-2): 4-21.
Kaltsatou A, Mameletzi D, Douka S (2011) Physical and psychological benefits of a 24-week traditional dance program in breast cancer survivors. J Bodyw Mov Ther 15: 15.

Kenfield SA, Stampfer MJ, Giovannucci E, Chan JM (2011) Physical activity and survival after prostate cancer diagnosis in the health professionals follow-up study. J Clin Oncol 29(6): 726-732.

Khan NF, Mant D, Carpenter L, Forman D, Rose PW (2011) Long-term health outcomes in a British cohort of breast, colorectal and prostate cancer survivors: a database study. Br J Cancer 105(Suppl 1): S29-S37.

Kim CJ, Kang DH, Smith BA, Landers KA (2006) Cardiopulmonary responses and adherence to exercise in women newly diagnosed with breast cancer undergoing adjuvant therapy. Cancer Nurs 29(2): 156-165.

Maddams J, Brewster D, Gavin A, Steward J, Elliott J, Utley M, Moller H (2009) Cancer prevalence in the United Kingdom: estimates for 2008. Br J Cancer 101(3): 541-547.

Martin KA, Sinden AR (2001) Who will stay and who will go? A review of older adults' adherence to randomized controlled trials of exercise. J Aging Phys Activ 9(2): 91-114.

McKenzie DC, Kalda AL (2003) Effect of upper extremity exercise on secondary lymphedema in breast cancer patients: a pilot study. J Clin Oncol 21(3): 463-466.

Meyerhardt JA, Giovannucci EL, Holmes MD, Chan AT, Chan JA, Colditz GA, Fuchs CS (2006) Physical activity and survival after colorectal cancer diagnosis. J Clin Oncol 24(22): 3527-3534.

Meyerhardt JA, Giovannucci EL, Ogino S, Kirkner GJ, Chan AT, Willett W, Fuchs CS (2009) Physical activity and male colorectal cancer survival. Arch Intern Med 169(22): 2102-2108.

Michie S, Ashford S, Sniehotta FF, Dombrowski SU, Bishop A, French DP (2011) A refined taxonomy of behaviour change techniques to help people change their physical activity and healthy eating behaviours: the CALO-RE taxonomy. Psychol Health 26(11): 1479-1498.

Mishra SI, Scherer RW, Geigle PM, Berlanstein DR, Topaloglu O, Gotay CC, Snyder C (2012a) Exercise interventions on health-related quality of life for cancer survivors. Cochrane Database Syst Rev 8: CD007566.

Mishra SI, Scherer RW, Snyder C, Geigle PM, Berlanstein DR, Topaloglu O (2012b) Exercise interventions on health-related quality of life for people with cancer during active treatment. Cochrane Database Syst Rev 8: CD008465.

Musanti R (2012) A study of exercise modality and physical self-esteem in breast cancer survivors. Med Sci Sports Exerc 44(2): 352-361.

Perna FM, Craft L, Freund KM, Skrinar G, Stone M, Kachnic L, Youren C, TA B (2010) The effect of a cognitive behavioral exercise intervention on clinical depression in a multiethnic sample of women with breast cancer: a randomized controlled trial. Int J Sport Exercise Psychol 8: 36-47.

Pinto BM, Clark MM, Maruyama NC, Feder SI (2003) Psychological and fitness changes associated with exercise participation among women with breast cancer. Psychooncology 12(2): 118-126.

Pinto BM, Frierson GM, Rabin C, Trunzo JJ, Marcus BH (2005) Home-based physical activity intervention for breast cancer patients. J Clin Oncol 23(15): 3577-3587.

Pinto BM, Papandonatos GD, Goldstein MG, Marcus BH, Farrell N (2013) Home-based physical activity intervention for colorectal cancer survivors. Psychooncology 22(1): 54-64.

Richman EL, Kenfield SA, Stampfer MJ, Paciorek A, Carroll PR, Chan JM (2011) Physical activity after diagnosis and risk of prostate cancer progression: data from the cancer of the prostate strategic urologic research endeavor. Cancer Res 71(11): 3889-3895.

Rock CL, Doyle C, Demark-Wahnefried W, Meyerhardt J, Courneya KS, Schwartz AL, Bandera EV, Hamilton KK, Grant B, McCullough M, Byers T, Gansler T (2012) Nutrition and physical activity guidelines for cancer survivors. CA Cancer J Clin 62(4): 242-274.

This work is published under the standard license to publish agreement. After 12 months the work will become freely available and the license terms will switch to a Creative Commons AttributionNonCommercial-Share Alike 3.0 Unported License. 